\title{
No Muslim is just a Muslim: Implications for education
}

\begin{abstract}
It is widely accepted in academia and state policies that recent years have seen an increasing stress on publicly enacted Muslim identity in Britain and in many other parts of the world. Less recognized is the fact that many among those who call themselves Muslims do not share religion as predominant identity-attribute for themselves. Such people go by many appellations including secular Muslims, cultural Muslims etc. Similarly, that which goes by the name of Muslim culture is indeed a 'religio-secular' culture. Despite this reality, media, policy and educational discourse about Muslims continues to work with the binary of Muslims as religious and the West as secular. This means we are raising new generation in an empirically unsound and socially unhealthy image of the self and the other. This article will trace the rise of religion as the predominant pubic identity-attribute, challenge this phenomenon by showing its empirical vulnerability and detrimental social effects, and propose the need to reconceptualise the nature of identities attributed to people with Muslim heritage in pedagogical narratives.
\end{abstract}

\section{Keywords}

Islam, Muslims, religious education, religification, identity, Muslim cultures, secular 


\section{No Muslim is just a Muslim: \\ Implications for Education}

\section{Introduction}

Identities are half imagined, and usually more so than commonly recognised. Imagined not in the sense that we can make ourselves into whatever we want, but in the sense of constructing and choosing from possibilities that were created, to use Karl Marx's words, 'under circumstances existing already, given and transmitted from the past' (1963).

Sudipta Kaviraj (2014) proposes a useful distinction between identity-attributes and identity functions. For him, 'an individual does not have many identities; rather each individual's identity is complex... a combination of many features' which he calls identity-attributes. He describes identity function as 'a capacity to select, emphasize and mobilize into appropriate social acts the congeries of attributes that I possess at any point in time' (p. 2-3). A person can have many identity-attributes, religious, ethnic, professional, familial and so forth. She also has the ability to functionalise, i.e. choose, stress and deploy these attributes. ${ }^{1}$ Less noted in Kaviraj's analysis is the role of social recognition in identity formation. For functionalisation of an identity-attribute to succeed, it needs also to be recognised by the wider society. In fact, sometimes the larger social context is itself instrumental in amplifying certain identity attributes. As we will see below, in the case of Muslims, the functionalisation of religiousattribute of identity happened partly because it was quickly and widely recognised in media, politics and education.

The complex nature of identity, a fusion of given and imagined as well as proclaimed and recognised, is movingly captured by Rabindranath Tagore (d.1941) in his novel Gora. The protagonist in the novel, called Gora because of his extraordinary fair complexion in the context of Bengal where the story was set, is a staunch follower of Brahmanism, orthodox to the core and opposed to reforms. This bold and domineering figure is left with a severe identity crisis when his supposed mother tells him that he was not her son, and therefore not a Brahmin, but an Irishman left in her care because of the murder of his parents in the violence of 1857. As Sen puts it in Identity and Violence, 'at one stroke, Gora's militant conservatism is undermined by Tagore since Gora finds all the doors of traditionalist temple closed to him - as a "foreign born"” (2006, p: 38). In the end, Gora comes out of his crisis by choosing from multiple 
attributes, a more universal attribute of seeing himself as an Indian and as human being, adopting cosmopolitan perspective thereby rising above parochial identities of caste and religion.

Kaviraj also notes that identity attributes are of two kinds, those that are 'strictly individual like my taste in clothes, or my bodily features', and those that one 'can bear only because there are collective groups bearing those names', for example “"being a Hindu/Muslim” or a Labor Party supporter'. My interest in this article is mostly the latter, the collective identity attributes. I wish to explore how, over the last few decades, the identity attribute of Muslimness came to be functionalised as the primary attribute for a large number of people in Britain, both in terms of proclamation and recognition. As the functionalisation discussed is about religious attribute, this shift can be called religification (Ghaffar-Kucher, 2012; Panjwani, 2013). I am further interested in how this functionalisation serves the growing perception of Muslims and their cultures as the 'Other' of the West. I will then argue that there is a need to reconsider the primacy of religious attribute, as found in many curricular texts, by humanising Muslims by taking account of their religio-secular contexts and by reconsidering their varying attachments to religion. Finally, I will reflect upon the role of education in challenging religification.

\section{The context}

Recent decades have seen an increasing stress on Muslim or Islamic identity-attribute, both as self-perception on the part of many Muslims and as recognition by others, thereby making it a publicly enacted phenomenon. This amplification of Muslim identity has taken many forms: from changes in language and dressing to prominence of Islam in governance and political activism and across a range of regions in the world (Esposito, 1983; Tamimi, 2001; Klausen, 2005; Ahmad \& Evergeti, 2010; Ahmed, 2011; Inge, 2017; Hamid, 2016;). It also shapes state orientation and is reinforced by sections of media. As part of this wider trend, publicly enacted concept of 'British Muslims' is an emerging and dynamic social, religious and political phenomenon. As Modood and Ahmad (2007) note, though Asian 'still has some resonance as a self-identity for some, especially young people, mainly in relation to a new, hybrid British Asian culture, ... it is 'Muslim' that has emerged as the most prominent and charged communal category' (p.187). It needs to be recalled that the British state has approached Muslims as a community, or occasionally communities, since the colonial times when both the conception of history (Hindu period, Muslim period) and society were framed along communal lines (Metcalf, 1982). To be sure, the growth of Muslimness in recent decades must also be seen as 
part of a wider resurgence of religion in many parts of the world (Berger, 2002; Sacks, 1991; Rosenblum, 2000; Marty, 2003).

One outcome of this 'revival' of Muslim identity is the growing attention to Islam and Muslims in education in the West. Education systems in most western countries now teach about Islam, though the mode of incorporation of 'Islam' varies (Jonker and Thobani, 2009; Aslan, 2013; Wiseman, 2014). In some cases, such as Germany and Austria, Islam is taught in public schools to Muslims, as a confessional teaching; in others, the United Kingdom, for example, Islam is part of religious education, but has a unique place among school subjects as its syllabus is developed locally; in France, there is no specific school subject that deals with religion so Islam (as any other religion) is not taught with any distinct teaching content but matters related to Islam and Muslims can be drawn upon in various subjects such as history and art (Berglund, 2015). There are also a growing number of Muslim educational institutions, including online offerngs, providing confessional education to young Muslims in search of their identity, seeking what they see as the 'true' Islam. Later in the article I will come back to the implications of curricular representations and the need to revisit current representations of Muslims in education. Before doing that, I will explore how religion came to be the primary identity-attribute of those who are now called the British Muslims. The analysis will show the contingent nature of identity and the historical process that underlies the dominance of a particular identity-attribute.

\section{The making of publicly enacted Muslim identity}

Muslim presence in Britain can be traced back to the eighteenth century, and arguably even

earlier. ${ }^{2}$ The starting point in this exploration is Ansari's (2004) observation that most Muslims who came to Britain during $18^{\text {th }}$ and $19^{\text {th }}$ centuries 'did not publicly act under the label "Muslim" and were not even necessarily perceived as such by the wider society, but on the whole in broader racial terms' (p. 24). The interactions between peoples from Britain and those who came from abroad, was mediated as much, if not more, by colour, race and social status as by religion. ${ }^{3}$

The beginnings of transformation lay in the late nineteenth century. As people from different regions of the Empire bagan to have longer and more stable stay in Britain, religion started to emerge as a common element among some of them. This was rooted in their similar concerns - for example, procuring halal meat - or facing tensions - for example over Azan (call to prayer) 
in Liverpool in 1891 (Ansari, 2004). International factors, such as the Mahadist Wars in Sudan and particularly the death of Major General George Gordon in 1885, added to the hostility towards Muslims among some sections of British population (Dekmejian \& Wyszomirski, 1972), furthering, in response, the sense of Muslimness in a foreign land.

The late nineteenth century also saw the institutionalisation of Muslim presence in Britain. A mosque in 1889, in Liverpool, established by an English convert William Abdullah Quilliam, is often regarded as the first step in this process. Soon there was also a Muslim Institute (Germain, 2007), publishing weekly and monthly journals (Robinson-Dunn, 2003). Almost the same time, another institutional development was taking place in Woking, South England, where an Oriental Institute and Shah Jahan mosque were built in 1889 by Dr Gottlieb Wilhelm Leitner (Ansari, 2004). The Institute served as an educational centre for Muslims, publishing a journal and organising various activities, including language courses for British officials to be posted to India. The importance of Woking Institute was crucial in making South Asians prominent in Muslim affairs, a fact of far reaching consequences. The Woking mosque and Institute remained in the limelight until 1940s, after which they were eclipsed by the establishment of East London Mosque and the London Central Mosque in Regent's Park in 1941 and 1944, respectively. ${ }^{4}$

\section{Muslim identity in the post WWII period}

The immediate factors leading to the recent crystallisation of Muslim identity are to be found in the post-World War II period which saw a significant increase in migrant population in Britain. Most of those who came to be seen as British Muslims arrived from South Asia (Nielsen, 1989). As a result, next decades saw new dynamics in religion, culture and politics. As we will see below, though religion was always an important identity-attribute in Muslim contexts, its heightened, and sometimes almost exclusive, functionalisation has to do with a host of factors. Given that our main concern in this special issue is on education and identity, I will trace the development of the dominance of Muslim attribute as public identity by exploring the relationship between the two.

\section{Education and Muslim identity}

Educational concerns played a very important role in bringing together Muslims of different ethnic and national backgrounds, forging a shared sense of 'Muslim efforts' to advocate and petition (Ansari, 2004; Fetzer, 20065). By the end of the 1950s, and certainly by mid 1960s, 
education had become a major concern of new migrants, as the men, who formed the bulk of initial wave of migration, were joined by their families (Goldman and Taylor, 1966). Large sections of the new immigrants settled in the industrial cities such as Glasgow, Newcastle, and Manchester where the educational facilities were far from satisfactory, by government's own admission (HMSO, 1963, 1967). A key consideration, which was to play an important role in education, as well as more generally in Muslim context, was the fact that a large proportion of South Asian immigrants were from working class and rural background; Mirpur in Pakistan, Sylhet in Bangladesh and rural parts of Indian Punjab. Their kinship structure (Biradari) and system of reciprocal giving and receiving (len-den) provided the social backdrop to migration and settlement (Shaw, 2000) and the desire to sustain some of these traditions - particularly with respect to gender roles (the notion of izzat (honour)), for example - became a key factor in educational context.

The early policy response from the state concerning the educational issues of the new immigrants was based on the twin assumptions that 'immigrant children would be working class' and that 'the specific educational "deficit" of white working-class pupils would apply equally and automatically' to the newly arrived children (Ansari, 2004, p. 299). Therefore, the then existing physical facilities, pedagogical approaches and curriculum content were deemed fit for migrant children. The 'working class' assumption was underpinned by a further supposition which held that the newly arrived would seek to assimilate the British culture, albeit at the lower levels.

Soon it became apparent that both these assumptions were flawed. Having taken the risk of leaving their countries, migrants were not satisfied with their existing status. They sought social mobility, if not for themselves, surely for their offspring. The assimilation assumption too turned out to be wrong. The migrants, and particularly their children, were not willing to accept a secondary social position. As a result, from the late nineteen sixties and particularly in the seventies, South Asian migrants began an active involvement with the policy issues related to their children's education. They did so increasingly on religious rather than ethnic grounds. From the late 1960s, there began to emerge groups that spoke as 'Muslims', articulating their religious point of view on various educational matters.

It was, however, not inevitable that migrants would come to approach education predominantly from religious point of view. In fact, many educational issues faced by the migrant 
communities were common across the South Asians and Caribbeans. The educational and political literature of the period, that is 1950 s and 60s, mostly used the terms black or 'coloured' for all new commonwealth immigrants. Thus, education could have become a minority issue, with Caribbean and South Asians joining hands. People from South Asia could have campaigned for education of their children jointly, overcoming the national and religious differences. Finally, there could have been the strengthening of national identities, with people campaigning as Pakistanis or, post-1971, as Pakistanis, Indians and Bangladeshis. While all of these identity markers did play a role, and continue to do so in some ways, in the end the voice that got associated with education the most was religious. ${ }^{5}$

\section{Factors in the emergence of Muslim identity}

We will now consider factors that facilitated the emergence of a strong Muslim identity. These are many and inter-related. Their force, it must be noted, lies in their cumulative impact, not individually.

\section{Religious attachment and institutionalisation}

The few studies in the 1960s that explored the importance of religion within the migrants found religious attachment to be stronger among Muslims than in other groups (Hiro, 1971; Taylor, 1976). Taylor also noted that young Muslims were least inclined to change anything in the religious tradition and most likely to stress the difference between their religion and Christianity. Thus, even when religious identity was not seen as central in the migratory experience of South Asians (perhaps influenced by the secularization thesis), it was strongest among Muslims than in the people of other religions.

This religiosity sought expression for which mosques were the obvious avenues. As the number of Muslims increased in Britain so did the number of mosques, from 13 registered mosques in 1963 to 49 in 1970 and to 193 by 1980 (Nielson, 1995). In addition congregational prayers, mosques served as educational centres for teaching religion to children and as community gathering places where shared social issues faced by Muslims were discussed. Out of such discussions, emerged organisations that started to campaign and advocate for 'Muslim issues'.

One of the earliest organisation was the UK Islamic Mission set up in 1962. The Union of Muslim Organisations (UMO) was established in 1970. While these focused on 'Muslim concerns' in all walks of life, thereby translating many social issues into religious, other 
institutions came about to focus mainly on educational issues. One of the earliest was Muslim Educational Trust (MET), which started in 1966 (Mustafa, 2001). These entities played considerable role in delineating the directions for Muslim communities as they settled in the UK. Often, they led the discourse on the need for children to have a Muslim upbringing. For instance, a pamphlet by the Union of Muslim Organisations issued in 1975 emphasised upon Muslim parents 'to be more conscious than they presently are of their duty to conform the education of their children' and ensure that it is in line 'with the principles and requirements of Islam' (Iqbal, 1975, p. 5). It can be postulated that the members of these educational organisations saw religious identity as extremely important and petitioned its centrality among those who may have been otherwise less inclined to see religion central to their lives.

\section{Concerns around girls' education}

In 1983, the Muslim Educational Trust produced a pamphlet listing seventeen 'educational problems' faced by Muslims in schools (Sarwar, 1983). Most prominent were moral and cultural issues: identity, single sex schools, halal food, uniform, Arabic teaching, prayer facilities and so on. Academic concerns did not feature at all.

Among these 'educational problems' of Muslims, that of the girls' education was emotionally most charged. Hewer put the concerns around girls' education as the first in his list of factors leading to the demand for Muslim schools (Hewer, 2001). The turning point was 1973 when a parent sent his daughter back to Pakistan after she was refused admission into a single sex school (Halstead, 1988). During the same time, the Union of Muslim Organisations (UMO) of United Kingdom and Eire published a pamphlet arguing for single sex schools (Iqbal, 1975). The pamphlet titled Islamic Education and Single Sex Schools is very relevant here as it provides an interesting example of rhetorical strategies employed in transition towards the formation of a Muslim identity. The pamphlet drew upon an academic research in migrant communities to make a case for single-sex schools. It quoted Sue Wallis's article Pakistanis in Britain (Wallis, 1974-5) which made a sociological argument for single sex schools for girls on the basis of its finding that the number of girls in the Pakistani community was far outnumbered by boys. This imbalance was because many parents, at that time, sent their female child back to Pakistan for education and broader cultural upbringing. Wallis argued that Pakistani girls, therefore, had limited opportunities for developing female companionship. The UMO pamphlet converted this finding of a social-psychological nature into a religious matter by positing a strong link between education and character building and then claiming that the 
'mixing of the sexes in and out of school at the adolescent stage' as a prime concern of Muslim parents. It argued that from an Islamic point of view the status of women was to be full time wives and mothers (p. 12). Unlike Wallis's concern, the document's main problem with mixed education was that it cannot prepare girls for their proper role in life - motherhood. ${ }^{6}$

\section{Rise of the New Right}

Among the most salient factors contributing to the emergence of public Muslim identity in Britain was the shift in the government policies away from the multicultural approaches of the 1970s. With this shift towards the market and national culture as the overall economic and social framework for state policies, schools came to be regarded as a major site for the inculcation of 'appropriate' values (Francis, 1990). Education Reform Act of 1988 and the National Curriculum were among the clearest articulations of the new approach. There was a move away from an earlier discourse of social justice and equality to that of standards, choice and centralisation. The Act stressed the centrality of Christianity in Great Britain while acknowledging the presence of other religions. It mandated the daily act of worship in schools and required that the religious education should 'reflect the fact that the religious traditions in Great Britain are in the main Christian whilst taking account of the teaching and practices of the other principle religions represented in Britain' (DES, 1989).

Many Muslims saw the Act as a departure from the gains of the multicultural approach of the seventies and early eighties. The Muslim Education Trust, for example, in its booklet What can Muslims do? (MET, 1989) expressed reservations about the Act and listed various ways Muslim parents could register their protest. It recommended that parents make use of the option to withdraw from schools assemblies.

Perhaps the most vivid example of the resulting ethnic tensions, collision of different positions regarding educational policy and the hardening of ideological positions was provided by the Honeyford Affair (Demaine, 1993; Halstead 1988). Ray Honeyford was a head teacher of a Bradford school with majority of non-white children. In 1984, he wrote an article in the Salisbury Review criticizing multicultural policies in education using the language that many saw as highly critical of Asian and Muslim cultures. The resulting debates brought to the surface deep tensions and divergent policies about education's relationship with culture. It was in these debates that the word 'Muslim' became as much of, or more, of an identity marker as 
Pakistani, Indian or Black was until then. The debate hardened attitudes on both sides (Halstead, 1988).

\section{Muslim schools}

The growth of Muslim faith schools in the UK is reflective of as well as contributor to the growing strength of religious identity. The first Muslim school was opened in 1979 in Lancashire. In 2013, according to the website of the Association of Muslim Schools (AMS), there were 156 full time Muslim schools. The advocates believe that though only 5\% of Muslim children attend these schools, the demand is much greater, with most schools over-subscribed. Promotion of a Muslim identity through an education that they see fit for contemporary times is their primary aim. Recalling the early days of the demand for Muslim schools, Dr. Mukadam, one time Chairman of Association of Muslim Schools observed in an interview that during 1970s and 1980s many devout and practising Muslims felt that if they wish to preserve their religious identity they must follow suit of Christian and Jews who have set up their own schools: 'Muslims felt that there is a big danger here, if our children would go to their [comprehensive] schools which are secular where there is no religious environment. Our children must be saved from such an environment. Then first schools began to emerge.' (Panjwani 2009). The aim of preserving and promoting identity remains important for Muslim schools. The mission statement of the Islamia Primary school, for example, states that it strives 'to provide the best education within a secure Islamic environment through the application of the Qur'an and Sunnah.' (Islamia, n.d.).

Here it is import to note that converts to Islam have played a significant role in the development of the idea and practice of Islamic education, including Muslim faith schools. Heads of several Muslim schools and writers of influential papers on Islamic education happen to be converts. This makes sense as, having consciously chosen it, Muslim identity is likely to be central for them and given their in-depth familiarity with the educational system it would be natural for then to rise in the school hierarchy. The role of converts, though under researched, is very important in the process of religification of Muslim identity in the UK, both through schools and more generally.

\section{Felt double alienation}

Research conducted in nineteen eighties and nineties into the identity formation among young Caribbeans and South Asians showed that many young people were uncomfortable calling themselves British - beyond a legal title - as they felt unaccepted as co-citizens by the majority This sense of felt alienation, rooted in the disadvantages in education, employment, housing 
and political participation, has been seen as one of the most powerful reasons for the emergence of strong Muslim identity in Britain (Modood, 1989; Modood et al, 1997;). If the first generation experienced any sense of being less than full citizens, and it surely did, its 'myth of return' made it appear as a short-term difficulty for a greater good, often seen in terms of quality education for their children (Anwar, 1979). But, the subsequent generations of Muslims grew up far more self-assured of their citizenship and did not feel indebted to their country of birth. Without any mitigating factors, difficulties in integration had a far deeper impact on them (Nielsen, 1987), including a turn towards religion for sense of belonging.

In fact, many among the second and third generation felt doubly alienated, in addition to broader societal alienation, also felt an inter-generational alienation within the communities and families (Abbas, 2004). The latter often forced them to negotiate what came to be known as the 'two cultures', negotiating their daily lives among the sometimes conflicting perceptions and demands of home and school (Bhatti, 1999). A very remarkable inter-generational flashpoint for some young people was around the attitude to marriage. The traditional attitude to marriage - arranged and within community - was challenged by many youngsters in Britain by marrying by their own choice and often outside the community structure, and justifying it through an appeal to Islamic allegiance beyond race and ethnicity. These youngsters came to see their parents' practices as cultural innovations, nothing to do with pure religion which many of them associated with the Arab-centric religious interpretations. It can be argued that these youngsters were exercising personal autonomy, though they saw it as an 'Islamic' rather than a liberal act (Schmidt, 2004).

\section{Transnational links}

There were factors outside of Britain that, through transnational connections, contributed to the strengthening of Muslim identity. Most importantly, from 1970s there emerged a growing trend of 'return to Islam' in some Muslim majority countries from where migrants were coming to Britain. Much has been written to show that a wide range of theological, social and political factors came together to heighten the sense of religious identity in Muslim majority countries (Ayubi, 1980; Esposito and Tamimi, 2002; Nasr, 2003). The most visible form of this revival was political-militant, culminating over decades into Taliban, al-Qaeda, ISIS and other entities. For our purpose, however, more relevant was the socio-cultural dimension of religious revival, the process of Islamisation, the increasing desire to become Islamic in food, dress, financial transactions, salutation and other elements of everyday life. In some cases, like the rule of 
General Zia in Pakistan in 1980s, the Islamisation trend was vigorously pursued as a state agenda (Awan, 2012). In others, such as the Saudi Arabia, the Wahabi interpretation of Islam was powerfully spread in Muslim contexts, with full support of the financial resources of the state, resulting in very significant changes in the nature of religiosity across the Muslim countries (Birt, 2005). Many Muslims who came to Britain in the eighties and nineties experienced this resurgence in their respective countries.

It can be seen from the above that a range of factors came together to make Muslimness a publicly enacted identity-attribute. Their impact was cumulative and ranged from challenges of migration to global geopolitics.

The defining moment for the crystalisation of Muslim public political identity was the Rushdie Affair. Protests against Satanic Verses in 1988 are often seen as the culmination of the politicisation of British Muslims. Though these protests were portrayed as reminiscent of a medieval mind-set and repulsive from post-Enlightenment perspective, for many Muslims the reaction of British press and intelligentsia demonstrated that:

... Western societies were not interested in understanding why they [Muslims] were so deeply offended by its publication. Rather, the political establishment went so far as to inform Muslims that they lived in a civilized society and should behave accordingly by following its norms and expectations. (Khan, 2000: 34 quoted in Poynting \& Mason, 2007)

This feeling of mutual incomprehensibility only got worse in the subsequent years.

\section{Why it matters to rethink religiofication of Muslims?}

Religification as a social phenomenon has several social and political implications. As will be argued below, in the case of religification of Muslimness as public identity, the implications are not wholly good and need serious consideration.

To begin with, religification of Muslims acts as a 'discourse of difference' (Zubaida, 2010) and serves to reinforce the perception of alterity between the so called Muslim cultures and the West. The advocates of difference create markers around which chasm is deepened and sustained. Most obvious of these dichotomising markers is the division into 'the religious 
Muslim' and equally problematic 'the secular West'. Another well know example of such divisive markers is in Huntington's thesis of 'clash of civilisations' where he categorises cultures according to the value of individuals, claiming that the respect for the individual is unique and indigenous to the West; non-western cultures, including Muslim cultures, were communitarian and authoritarianism in their very makeup (Huntington, 1996). Within the educational context, the idea of autonomy has come to assume the fault line with both the proponents and opponents of Islamic education claiming that failure to see autonomy as an educational ideal marks the difference between Islamic and liberal conceptions of education (Halstead, 1985; Tinker, 2006). ${ }^{7}$

Racialisation of Muslims has be argued as another consequence of religification, where by an internally very diverse community is perceived as 'a homogenous, undifferentiated mass,' 'with presumed deterministic values diametrically opposed to, and threatening the values of the civilized West' (Ahmad and Evergeti, 2010). There is then two layers of reductionism taking place; the diversity of identity-attributes are compressed to a religious attribute (religifcation) and the religious differences too are denied to create a single homoginsed Muslim (essentialism).

This then often leads to another consequence, ascribing agentive power to identity. Individuals are seen to be acting as single collective actors. As Kaviraj puts it:

Under this altered optics of belonging, agency and responsibility, it becomes possible to be fluent in the deadly languages of modern hatred. Muslims are seen to have destroyed the towers at the World Trade Centre, in retaliation for indignities that Americans had heaped on the populations of the Middle East. It is pointless to show that this language uses an improbably expanded notion of political agency and moral responsibility, or that it does not allow for a slope of agency and culpability inside the hateful collectivities' (p. 4).

Another, and comparatively less discussed, consequence of religification in this case is the loss of rich cultural narratives and resources. Ethnic South Asian, Pakistani, Indian or Bengali identities carry with them rich cultural traditions of literature, dance, music, sartorial styles, culinary, architecture, languages and mannerism. Much of these was suspect for those who were attracted to austere interpretations to which many in the second and third generation 
young people were drawn (Inge, 2016). This huge cultural loss was of significance for at least two reasons: a) it deprived the young people of learning about the range of ways in which Muslims have integrated religious ideals with cultural traditions and b) made the culture of the West appear more alien to Islam than it otherwise would have been.

The problem of religification is also found in the education. It was noted earlier in the article that one of the outcomes of the heightened attention to Muslim identity was expanding provision for Islam and Muslims in educational systems in the West. With some exceptions, as depicted in most of the textbooks in these systems, the ascribed identity of 'Muslims' is primarily religious (Panjwani, 2013; Revell, 2009; 2010; Thobani, 2010), presented as a people who once reigned over a large part of world, and made significant and pioneering contributions in philosophy, medicine, astronomy in addition to religious thought. In contemporary times, their lives are shown to be revolving entirely around religion, thereby approaching lives and the world at large through it. For example, there are books whose focus is Muslims, not Islam, and yet, they discuss only the religious dimensions - ritual, beliefs, scriptures, festivals - as if a Muslim has no interest, capacity and aspirations beyond the sphere of religion (Knight, 1999; Siddiqui, 2008; Thompson, 2000). ${ }^{8}$

It is important to recallthat the religification of Muslims is not only a matter of perception, representation and imposition by the others. . It is collectively proclaimed, in the sense that there are many Muslims who see themselves and the world around them primarily through a religious identity. They see the religious attribute of their identity as the foremost attribute, a crucible in which all other attributes find meaning. The outlook and practices of such people makes up a strong proportion of the so the called Muslim world - but to view the whole societies through their lens is to do injustice to the actual lives and humanity of people.

These detrimental effects of religification, both for Muslims and for wider geo-politics, in addition to the fact that it misrepresents the empirical reality of Muslims, provides sufficient ground to challenge it. As I have tried to argue, the heightened functionalisation of Muslim identity in Britain was a contingent and gradual process. Functionalisation of an identityattribute, no matter how strong, is always alterable because it is never the only attribute (Kaviraj, 2014). This opens up the possibility that with a different set of socio-political factors, a modified form of religious identity, perhaps more open to an 'overlapping consensus' among different traditions of beliefs that have to live together (Rawls, 1993). 


\section{Education and rethinking of Muslim identity}

No Muslim is just a Muslim. This is precisely what some recent writings have started to point out, challenging the unidimensional presentation of Muslims and their cultures (Zubaida, 2010; Marranci, 2010; Panjwani; 2013; Martin, 2010). Martin observes that there are many secular Muslims who are not given due attention in media and academia. He defines secular Muslims as those who

while retaining some form of Muslim, if not Islamic identity,...lead secular lives and think through most of life's problems and challenges by means of secular worldview, though they may not necessarily renounce their faith or think ill of family and friends who are religious (p.131).

In the same vein Zubaida notes that

In the Middle East, and much of the 'Muslim world', we have the paradox of largely secularized societies and polities combined with the espousal of sacralised ideologies by regimes and oppositions. The societies are secularized in that many of their institutions and practices have no relation to religion. (Zubaida, 2010:4)

These observations are well supported by empirical studies. For example, a recent Pew Research survey concluded that 'common belief does not necessarily mean that religion is equally important to the lives of all Muslims. The importance Muslims place on religion varies significantly by region' (Pew, 2012).

Educationally then, the first step will be to bring the portrayal of Muslims closer to the empirical reality, as noted above. That is to bring out the fact that religion plays very different roles - from being a necessity to maintain social ties to being a complete way of life. This can be done by introducing students, not to 'Muslim history' or 'Muslim society', but to the societies of the regions and countries where Muslims live. In studying these societies, students would learn that being a Muslim can mean a huge range of possibilities: those that believe that religion should guide politics to those who believe in secular politics; those who think that evolution is incompatible with Islam to those who work to understand and promote evolution; those who structure their lives around rituals to those who rarely participate in rituals; and, 
from those whose very appearance radiates their religion to those whose religion remains unknown even after scores of interactions.

One very useful way of exposing students to what Marty has called 'religio-secular' nature of Muslims is through literature and the arts produced in Muslim contexts. A good novel, for example can take the reader into the inner recesses of characters, their moral and psychological struggles, and beyond that provide insights into the consciousness of a people. It can create, 'a capacity for sympathetic imagination that will enable us to comprehend the motives and choices of people different from ourselves, seeing them not as forbiddingly alien and other, but as sharing many problems and possibilities with us' (Nussbaum, 1997: 85). Martin takes the example of the work of Orhan Pamuk to bring out the potential of literature to help students gain insights into the complex intersection of the secular and the religious in public and private lives (Martin 2010). Scores of other example can be added from Indonesia to India and from Algeria to Tajikistan which can show how religious beliefs mean very different things to different people and how little or large role it plays in individual, family and communal lives (Panjwani 2013).

To this, one can add the educational potential of drawing upon online and museum based resources of the arts from the Muslim contexts that can help students acquire a complex and nuanced understanding of people with Muslim heritages and overcome received impressions about a monolithic Muslim community. As Singh (2014), in his report on the cultural value of South Asian arts in Britain notes, 'despite the popular idea that Muslims do not engage with music, an analysis of some of the events taking place in Pakistani and Bangladeshi community centres highlights a number of music related events being organised for members of these communities' (p. 14). Interestingly, the quote also brings out the fact that for many people their ethnic identities of Pakistan and Bangladesh continue to remain important.

\section{Conclusion:}

Oliver Roy in a recent article about the French election noted that there are between 2 and 4 million Muslims in France, 'depending if we refer to believers or people from Muslim origin'. As Islam has not only been a religion in the sense of theological beliefs and practices but also a social and political orientation at the heart of many cultures, it is possible to be Muslim in a range of ways, as was noted above. Yet, this diversity is often neglected and Muslims are seen primarily through a religious lens, This article attempted to trace the rise of religion as the 
predominant pubic identity-attribute for Muslims in Britain. Drawing upon the work of Kaviraj and others, and taking identity as a dynamic fusion of given and the imagined, it explored how many decades, but particularly in the post WWII period, religion came to acquire primary identity attribute both in terms of being proclaimed and recognized. We then argued that this singular image needs to be challenged as it is empirically untrue and politically divisive, as this reductionist image can be deployed for social disharmony and fragmentation. In particular, it was argued that curricular narratives are eminently suitable in challenging this phenomenon.

Finally, it is important to note that though this article is about issues to do with Muslims, recent years have made it clear that the need to challenge singular identity-attribute is much wider. No Briton is only Briton; no Christian is only a Christian; no American is only American. This growing retreat into singular identity-attribute is harmful to all. As Ayers noted, this can force us to "live in our own inflamed identities with such fierceness that we tend to obliterate complexity, nuances, and truth' forgetting that 'we are each an entire universe, sailing through space. We are always more.' (Ayers, 2006) 


\section{References}

Abbas, T. (2004) The Education of British South Asians: Ethnicity, Capital and Class Structure. New York: Palgrave.

Ahmed, A. S. (1997) Jinnah, Pakistan and Islamic Identity: The Search for Saladin. London Routledge.

Ahmed, L. (2011) A Quite revolution: The veil's resurgence from Middle East to America. Harvard University Press.

Ahmad, W. and Evergeti, V. (2010) The making and representation of Muslim identity in Britain: conversations with British Muslim elites. Ethnic and Racial Studies, 33 (10). pp. 1697 1717.

Aslan, E. (2013) Islamic Education in Secular Societies. Frankfurt am Main: P. Lang.

Ansari, H. (2004) The 'Infidel' within: Muslims in Britain since 1800 London: C. Hurst \& Co.

Anwar, M. (1979) The Myth of return: Pakistanis in Britain. London: Heinmann.

Awan, M. S (2012). Impact of Radical Islamisation of Education on Pakistani Society, Pakistaniaat: A Journal of Pakistan Studies, 4(2): pp. 45-55. Available at: http://pakistaniaat.org/index.php/pak/article/view/163/163 [Accessed: 23 February, 2017].

Ayers, W. (2006) Trudge Toward Freedom: Educational Research in Public Interest. In Gloria Ladson-Billings and William F. Tate (Eds.) Education Research in the Public Interest. Teachers College: Columbia University Press.

Ayubi, N. (1980) The Political Revival of Islam: The Case of Egypt. International Journal of Middle East Studies, 12(4), pp. 481-499.

Bhatti, G. (1999) Asian Children at Home and at School. London: Routledge.

Berger, P. (2002) Secularism in retreat. In John Esposito and Azzam Tamimi, eds., Islam and Secularism in the Middle East London: Hurst \& Company.

Berglund, Jenny (2015) Publicly Funded Islamic Education in Europe and the United States. Washington: The Brookings Institution.

Birt, Y. (2005) Wahabism in the United Kingdom: Manifestations and Reactions. In Madawi Al-Rasheed (ed.) Transnational Connections and the Arab Gulf. London: Routledge.

Brotton, J. (2016) This Orient Isle: Elizabethan England and the Islamic World. London: Penguin.

Dekmejian, R. H., \& Wyszomirski, M. J. (1972) Charismatic Leadership in Islam: The Mahdi of the Sudan. Comparative Studies in Society and History, 14(2), pp. 193-214. 
Demaine, J. (1993) Racism, Ideology and Education: The Last Word on the Honeyford Affair? British Journal of Sociology of Education, 14(4), pp. 409-414.

DES. (1989) The Education Reform Act 1988: religious education and collective worship, Circular No. 3/89. London: HMSO.

Esposito, J., \& Tamimi, A. (eds.) (2002) Islam and Secularism in the Middle East. London: Hurst \& Company

Esposito, J. L. (1983) Voices of resurgent Islam. Oxford University Press.

Fetzer, J. S. (2006) Muslims and the state in Britain, France, and Germany. Cambridge: Cambridge University Press.

Francis, M. (1990) Race and the Education Reform Act. The Urban Review, 22(2), pp. 115129

Germain, E. (2007) Southern Hemisphere Diasporic Communities in the Building of International Muslim Public Opinion at the Turn of the Twentieth Century. Comparative Studies of South Asia, Africa and the Middle East, 27(1), pp. 126-138.

Ghaffar-Kucher, A. The Religification of Pakistani-American Youth. American Educational Research Journal 49.1, 30-52.

Goldman, R. J., \& Taylor, F. (1966) Coloured Immigrant Children. A Survey of Research Studies and Literature on their Educational Problem and Potential - in Britain. Educational Research, 8(3), pp. 163-183.

Halstead, J. M. (1985) The case for Muslim Voluntary-Aided Schools: some philosophical reflections. Cambridge: The Islamic Academy

Halstead, J. M. (1988) Education, Justice and Cultural Diversity: An Examination of the Honeyford Affair, 1984-5. London: Falmer.

Hamid, S. (2016) Sufis, Salafis and Islamists: The Contested Ground of British Islamic Activism. London: I.B.Tauris.

Hewer, C. (2001) Schools for Muslims. Oxford Review of Education, 27(4), pp. 515-527.

Hiro, D. (1971) Back British White British. London: Eyre and Spottiswoode.

HMSO. (1963) Half our future: a Report of the Central Advisory Council for Education (England) [Online]. Available from: http://www.educationengland.org.uk/documents/newsom/newsom1963.html (Accessed 1 March, 2017).

HMSO. (1967) Children and their Primary Schools: a Report of the Central Advisory Council for Education (England). [Online]. Available from: http://www.educationengland.org.uk/documents/plowden/plowden1967-1.html [Accessed 1 March 2017] 
Huntington, S. (1996) The West: Unique, Not Universal. Foreign Affairs, Nov-Dec, pp. 28-46.

Inge, Anabel (2017) The Making of a Salafi Muslim Woman: Paths to Conversions. Oxford University Press.

Iqbal, M. (1975) Islamic Education and Single-sex Schools. London: Union of Muslim Organisations of UK and Eire

Islamia Primary school (n.d.) Our, Mission, Vision and Values. Online. Available at: http://islamiaprimary.org.uk/our-mission-vision-values/. [Accessed May 6, 2017].

Jonker, G and Thobani, S. (2009) Narrating Islam: Interpretation of Muslim World in European Texts. London Tauris Academic Books

Kaviraj, S. (2014) A Strange Love of the Land: Identity, Poetry and Politics in the (Un)Making of South Asia, South Asia Multidisciplinary Academic Journal [Online], 10 |2014, Available at: http://samaj.revues.org/3756; DOI : 10.4000/samaj.3756, [Accessed February 11, 2017]

Klausen, J. (2005) The Islamic Challenge: Politics and Religion in Western Europe. Oxford: OUP.

Knight, K. (1999) My Muslim Faith. London: Evans.

Marranci, G. (Ed.) (2010) Muslim Societies and the Challenge of Secularization: An Interdisciplinary Approach. Springer.

Martin. R. (2010) Hidden Bodies in Islam: Secular Muslim Identities in Modern (and Premodern) Societies. In Marranci, G. (Ed.) (2010) Muslim Societies and the Challenge of Secularization: An Interdisciplinary Approach. Springer.

Marty, M. (2003) Our religio-secular world. Daedalus, (Summer), pp. 42-48

MET. (1989) What can Muslims do? London: Muslim Education Trust.

Metcalf, B. (1982) Islamic Revival in British India: Deoband, 1860-1900. Princeton: Princeton University Press.

Modood, T. (1989) Religious anger and minority rights. Political Quarterly, 60(3), pp. 280284.

Modood, T. et al. (1997) Ethnic Minorities in Britain: diversity and disadvantages. London: Policy Institute.

Modood, T. and Ahmad, F. (2007) British Muslim Perspectives on Multiculturalism. Theory, Culture \& Society 24(2): pp. 187-213

Mustafa, B. (2001) Public Education and Muslim Voluntary Organisations in Britain. International Journal of Research \& Method in Education (formerly Westminster Studies in Education) 24(2), pp. 129-136. 
Nasr, V. (2003) Lessons from the Muslim World. Daedalus (Summer), 67-72.

Nielsen, J. (1987) Muslims in Britain: Searching for an identity? New Community, 13(3), pp. 384-394.

Nielsen, J. (1989). Muslims in English Schools. Journal of Muslim Minority Affairs, 10(1), pp. $223-245$.

Nussbaum, M. C. (1997) Cultivating humanity: a classical defense of reform in liberal education (Cambridge, Mass.: Harvard University Press).

Marx, K (1963) The Eighteenth Brumaire of Louis Bonaparte. New York

Panjwani, F. (2009) Rethinking the Educational case for Schools with Muslim Religious Character: Critical Analysis of the Conceptions of Knowledge and Autonomy. Department of Education. University of Oxford).

Pew (2012) The World's Muslims: Unity and Diversity. Online. Available at: http://www.pewforum.org/2012/08/09/the-worlds-muslims-unity-and-diversity-executivesummary/ [Accessed 1 March, 2017]

Panjwani, F. (2013). From 'Islamic' values to 'religio-secular' values in Muslim contexts: Educational implications of a conceptual shift. In: J. Arthur and T. Lovat (Eds). Routledge International Handbook of Education, Religion, and Values. 158-167.

Poynting, S. \& Mason, V. (2007) The resistible rise of Islamophobia: Anti-Muslim racism in the UK and Australia before 11 September 2001 Journal of Sociology 43(1): pp. 61-86

Rawls, J. (1993) Political Liberalism. New York: Columbia University Press.

Revell, L. (2009) Religious education, conflict and diversity: An exploration of young children's perceptions oi Islam. Educational Studies. 36(2), 207 -2015.

Robinson-Dunn, D. (2003) Lascar Sailors and English Converts: The Imperial Port and Islam in late 19th-Century England. Paper presented at Seascapes, Littoral Cultures, and TransOceanic Exchanges, Library of Congress, Washington D.C., February 12-15.

Rosenblum, N. (2000) Obligations of Citizenship and Demands of Faith: Religious Accommodation in Pluralist Democracies Princeton University Press.

Sacks, J. (1991) The Persistence of Faith: Religion, Morality and Society in a Secular Age. New York: Weidenfield \& Nicolson

Sarwar, G. (1983) Muslims and education in the UK. London: Muslim Educational Trust.

Schmidt, G. (2004) Islamic identity formation among young Muslims: the case of Denmark, Sweden and the United States. Journal of Muslim Minority Affairs, 24(1), pp. 31-45. 
Sen, Amartya (2006) Identity and Violence: the Illusion of Destiny, New Delhi: Penguin Books.

Shaw, A. (2000) Kinship and continuity: Pakistani families in Britain. Amsterdam: Harwood Academic

Siddiqui, H. (2008) Being Muslim. London: A \& C Black

Sivanandan, A. (1981) From resistance to rebellion: Asian and Afro-Caribbean struggles in Britain. Race Class, 23(2-3), pp. 111-152

Tamimi, A (2001) The renaissance of Islam Daedalus 132(3): pp. 51-8

Taylor, J. H. (1976) The Half-Way Generation: A Study of Asian Youth in Newcastle upon Tyne. Windsor: NFER

Thobani, S (2010) Islam in school curriculum: symbolic pedagogy and cultural claims. London: Continuum.

Thompson, J. (2000) The Muslim Experience. London: Hodder \& Stoughton.

Tinker, C. (2006) Islamophobia, Social Cohesion and Autonomy: Challenging the arguments against state funded Muslim schools in Britain. Muslim Education Quarterly, 23(1\&2), pp. 419.

Wallis, S. (1974-5) Pakistanis in Britain. New Community, 4(1), pp. 105-115.

Wiseman, A. (2014) Representations of Islam and Arab Societies in Western Secondary Textbooks. Digest of Middle East Studies, 23(2), pp. 312-344

Zubaida, S. (2010) Beyond Islam: A new understanding of the Middle East. London: I.B Tauris.

\footnotetext{
${ }^{1}$ Kaviraj builds his idea of identity-attribute by referring to Sen (2006) who had used the notion of multiple identities. While agreeing with the direction and spirit of Sen's conception, Kaviraj proposes an alternative framing: 'It is better to put it in a different way - an individual does not have many identities; rather each individual's identity is complex' (p.2).

2 There were domestic servants brought by the East India Company officials, sailors who came on ships sailing to the ports of England and Wales, students, candidates for civil service exams, ambassadors, political leaders, professors, professionals such as the doctors and exiled princes.

${ }^{3}$ See also Brotton, J. (2016)

${ }^{4}$ As these institutions were run by the Ahmedi community, their centrality was also affected by the growing intraMuslim tension with regard to the status of the community. Eventually Ahmedis came to be regarded as nonMuslims by many Muslim states and populations.

${ }^{5}$ Though they became significant minorities in Britain at about the same time, South Asians and Caribbean immigrants did not come close enough to form a common ground and join hands. This may be because Caribbeans and South Asians were employed in different industries, leaving little space for shared economic struggle and with different religious traditions, there were few shared communal places as well (Sivanandan, 1981). Further, for some Muslims the fact that the Caribbeans shared Christian religion with the majority British people made them part of the 'other' (Iqbal, 1975). At work here was a degree of intra-minority racism, a subject that needs further research. The other possibility, that of South Asian identity, was high, particularly given that the educational and political discourse of the time mainly used this term. Furthermore, some steps in this direction were also taken, for example, the formation of Indian Workers' Association in 1938. However, this possibility was squashed when, in 1947, South Asia was divided into two independent countries, India and Pakistan, a division that despite the presence of minorities in each country came to be seen as Hindu-Muslim divide. The
} 
memories of the divide were kept alive by the intermittent tensions and three wars between the two countries. Still, in the area of culture and art, a South Asian identity has emerged, particularly since 1980 s. ${ }^{5}$ In educational matters, the Indians and the Pakistanis have hardly co-operated.

${ }^{6}$ It is to be noted that the main reason boys outnumbered girls in Pakistani community was because many parents, at that time, sent their female child back to Pakistan for education and broader cultural upbringing.

${ }^{7}$ See Panjwani (2009) for a critique of this position.

${ }^{8}$ It must be noted though that beyond sharing religification problem, these books do differ in how they portray Muslims. So, one tells us that 'Muslim parents tend to be strict with their children. They often do not like them to go to parties and clubs' (Thompson, 2000: 49). And, another, far more nuanced book, recognises that Quranic teachings have been understood in many different ways. In discussing hijab, for example, it says, Muslim themselves have been divided on the subject" (Siddiqui, 2008: 54). 